\title{
INTERACTIONS BETWEEN NODDING THISTLE SEED PREDATORS
}

\author{
R. GROENTEMAN ${ }^{1}$, D. KELLY ${ }^{1}$, S.V. FOWLER ${ }^{2}$ \\ and G.W. BOURDÔT ${ }^{3}$ \\ ${ }^{1}$ School of Biological Sciences, University of Canterbury, Private Bag 4800, \\ Christchurch, New Zealand \\ ${ }^{2}$ LandCare Research, Gerald Street, PO Box 40, Lincoln, New Zealand \\ ${ }^{3}$ AgResearch, Gerald Street, PO Box 60, Lincoln, New Zealand \\ Corresponding author: rgr51@student.canterbury.ac.nz.
}

\begin{abstract}
The biological control program against nodding thistle, Carduus nutans, commenced in New Zealand in 1972, with the introduction of the receptacle weevil, Rhinocyllus conicus. Seed predation by the larvae of this univoltine weevil did not bring about the desired reduction in nodding thistle populations, and in 1992 a further seed predator was introduced - the bivoltine gall fly, Urophora solstitialis. Possible interference between these two niche-sharing agents may have resulted in less-than-additive seed predation. This recent study quantified the interactions between the two agents for the first time in New Zealand, and found the mean number of gall flies per seedhead was reduced by $46-93 \%$ in the presence of the receptacle weevil. This suggests that the weevil may limit the gall fly's populations, thus reducing seed predation later in the nodding thistle flowering period. The potential effects of this reduced attack on nodding thistle population growth rate were simulated using an existing matrix model.
\end{abstract}

Keywords: Carduus nutans, Rhinocyllus conicus, Urophora solstitialis, biological control, population dynamics.

\section{INTRODUCTION}

Nodding thistle, Carduus nutans, is a monocarpic weed of Eurasian origin, which relies solely on seeds for reproduction. In New Zealand, it has been shown that the high fecundity of the plant is an extremely important factor in its success (Shea et al. 2005), and should therefore be the stage targeted for biological control. In light of this, the introduction to New Zealand of nodding thistle receptacle weevil, Rhinocyllus conicus (Froehlich) in 1972 (Jessep 1989), following its success in controlling nodding thistle in North America, might have been expected to reduce the weed's densities. The weevil larvae feed on the receptacle of developing buds and thus prevent seed formation. However, the North American success was not replicated in New Zealand, possibly due to the extended flowering season of nodding thistle in New Zealand compared to North America and to the weed's native range, which allows most inflorescences in New Zealand to escape weevil attack (Kelly \& Wood 1991).

With seed production remaining the target for biological control, a further seed predator was introduced in 1992, the woody-gall-forming tephritid fly Urophora solstitialis L. This fly has two generations a year, and thus extends the period in which nodding thistle is exposed to attack (Woodburn 1996a). However, its first generation occurs simultaneously with $R$. conicus's (normally) single generation and, despite a claim that $U$. solstitialis actively avoids ovipositing in $R$. conicus-attacked capitula (Woodburn \& Sheppard 1995), the two species are known to co-occur in the same capitula (Zwölfer 1973, Harris 1989, Woodburn 1996b, McNeill \& Fletcher 2005, R. Groenteman, personal observations). 
Conflicting hypotheses exist as to which of the two seed predators is likely to be a superior competitor and which is likely to produce better control (Zwölfer 1973, Harris 1989). Experimental evidence on interspecific competition between the two species is sparse generally (e.g. Moller-Joop \& Schroeder 1986, in Carduus acanthoides), and non-existent for New Zealand. Retrospectively, Shea \& Kelly (2004) predicted that for a single biocontrol agent, $U$. solstitialis would have the strongest effect on nodding thistle population growth rate in New Zealand, but the lack of empirical data from New Zealand did not allow testing of this hypothesis.

This study quantifies the effect $R$. conicus has on $U$. solstitialis (and vice versa), and estimates how this might affect nodding thistle population growth rate.

\section{Plants and insects}

\section{MATERIALS AND METHODS}

Nodding thistle plants were grown in the University of Canterbury's glasshouses from seeds collected in summer 2005 in different parts of Canterbury. Seeds were sown in trays in a non-fertilised potting mix in late autumn 2005, and, in the winter were transferred to different sized pots, as well as transferred outdoors for vernalization. In early spring the plants were fertilised occasionally with nitrogen rich liquid fertiliser (Gro More $^{\circledR}$ by Gro-Chem NZ Ltd, 15:2:12 N:P:K) to induce an annual life cycle (flowering in the first summer). When rosettes reached suitable sizes, they were planted out in the experimental plot, an uncultivated grassy area that was regularly mown, at the Landcare Research Lincoln campus. The thistles were caged in groups of nine and biocontrol agent treatments were assigned to them.

To obtain $U$. solstitialis, galled nodding thistle capitula were collected from South Canterbury in summer and autumn of 2005, and were kept refrigerated until 3 weeks before adults were required in the experiment. At this time they were put in emergence cages with a thistle plant. Peak emergence occurred around 3 weeks from exposure to spring temperatures and daylight. Emerging U. solstitialis were collected daily and kept refrigerated in a ventilated container, until required in the experiment.

Adult $R$. conicus were collected using a leaf sucker during spring 2005 from South Canterbury and kept refrigerated in a ventilated container, until required in the experiment.

\section{Interactions between the two seed predators}

In each plot, nine thistle rosettes of various sizes were planted in a $3 \times 3$ arrangement, $30 \mathrm{~cm}$ apart, for a total of 45 plots (405 plants). Each plot was then caged in a $1.2 \mathrm{~m} \times 1.2 \mathrm{~m} \times 1.8 \mathrm{~m}(\mathrm{~L}: \mathrm{W}: \mathrm{H})$ fine mesh cage. To estimate each rosette size, the longest leaf was measured at the day of planting, and then again upon bolting. When about $40 \%$ of the plants had bolted, each cage was assigned one of nine seed predator density treatments. The nine treatments were $R$. conicus at zero, low (one couple) and high (three couples) densities and $U$. solstitialis at zero, low (five couples) and high (15 couples) densities, in all possible combinations (full factorial). The experiment was replicated five times in a randomized block design. Insects were again released in all the cages (except those assigned the zero $R$. conicus and zero $U$. solstitialis combination) around 3 weeks from the initial release, as a top-up, to replace mortalities. Plant height and number of primary, secondary and tertiary capitula were recorded fortnightly, and ripe capitula collected individually into paper bags, after having their individual height, position and external diameter recorded.

In the lab, the receptacle diameter was measured for each capitulum, and the seed predators' larvae and adults were counted. The differences in insect counts (log transformed) between treatments were compared in a mixed model in $\mathrm{R}$ (R Development Core Team 2006), with QuasiPoisson distribution. All different plant and capitulum variables were included in the model as covariates, and non significant variables were excluded in backwards selection using the Chi-squared test to compare between models. 
Simulation of the effect of the two seed predators on a nodding thistle population

Data from New Zealand on seed loss to biocontrol agents exist only for $R$. conicus, and were estimated at around 36\% (Kelly \& McCallum 1990). Estimates for seed loss to $U$. solstitialis were taken from Australian datasets, showing this fly reduced seed rain by close to $70 \%$ (the value used in our simulation) several years after its introduction (Woodburn \& Briese 1996). These values were inserted into an existing matrix population model for nodding thistle in New Zealand (Shea \& Kelly 1998), and the thistle population growth rate $(\lambda)$ was compared for the various combinations of biocontrol agents, assuming an additive effect.

\section{Interactions between seed predators}

\section{RESULTS}

Of the 405 plants in the experiment, 208 bolted, and 202 produced capitula at $4.59 \pm 0.19$ /plant (mean \pm SE). Mean external diameter of the capitula $( \pm$ SE) was $13.15 \pm 0.14 \mathrm{~mm}$. This is considerably smaller than nodding thistle plants typically found in New Zealand pasture. This could be due to the combination of poor soil at the experimental site, the caging of the plants (which may have reduced light intensity and rainfall and increased temperatures), and the timing of transplanting. Larger rosettes at planting were larger at bolting $\left(\mathrm{r}^{2}=0.46, \mathrm{P}<0.0001\right)$.

The mixed models show that both biocontrol agents preferred earlier, primary, higher, larger capitula on taller plants for oviposition (the difference between the best fit model and the next reduced model generating $\chi^{2}=5.466, \mathrm{P}=0.019$, and $\chi^{2}=5.94, \mathrm{P}=0.015$ for $U$. solstitialis and $R$. conicus respectively).

Both at low and high density, U. solstitialis showed a trend (albeit non-significant) of a decrease in numbers in the presence of $R$. conicus (Table 1). In contrast, $R$. conicus increased in numbers in the presence of $U$. solstitialis (Table 1). Thus, in the absence of $U$. solstitialis, final $R$. conicus numbers corresponded with initial $R$. conicus density: at low initial density, final numbers were significantly lower than at high initial density. However, this difference disappeared when U. solstitialis was present, especially when it was present at the high density

TABLE 1: Final density of $R$. conicus and $U$. solstitialis (individuals per 1000 capitula, fitted (backtransformed from log scale) means with $95 \%$ CI) in nodding thistle, given one of nine combinations of initial $R$. conicus and $U$. solstitialis density.

\begin{tabular}{|c|c|c|c|}
\hline \multirow{2}{*}{$\begin{array}{l}\text { U. solstitialis } \\
\text { initial density }\end{array}$} & \multicolumn{3}{|c|}{ R. conicus initial density } \\
\hline & 0 & Low & High \\
\hline & \multicolumn{3}{|c|}{ R. conicus final density } \\
\hline 0 & 0 & $40.9(15.0-111.3)$ & $471.2(234.6-948.4)$ \\
\hline Low & 0 & $93.4(38.3-228.1)$ & $523.9(238.9-1148.8)$ \\
\hline \multirow[t]{2}{*}{ High } & 0 & $342.6(148.1-792.2)$ & $398.9(185.0-860.3)$ \\
\hline & \multicolumn{3}{|c|}{$U$. solstitialis final density } \\
\hline 0 & 0 & 0 & 0 \\
\hline Low & $0.92(0.22-3.9)$ & $0.09(0.01-0.55)$ & $0.42(0.1-1.8)$ \\
\hline High & $9.4 \quad(3.1-28.6)$ & $5.4 \quad(1.7-17.9)$ & $3.5(1.1-108)$ \\
\hline
\end{tabular}


Simulation of the effect of seed predators interaction on a nodding thistle population

Despite the top-up release of insects in the experiment, it appears that adults of both species suffered high mortality, especially U. solstitialis. The back-transformed means of insects per capitulum (Table 1) are very low compared to numbers occurring in natural populations. The high adult mortality and low insects per capitulum recovered are probably artefacts of the caging. Therefore, to estimate the effect of seed predator combinations on thistle population growth rate, the differences between combinations were used, rather than the actual means. Table 2 details the expected nodding thistle population growth rates at different combinations of $R$. conicus and U. solstitialis, as calculated by modifying Shea \& Kelly's (1998) matrix. The greatest impact on thistle growth rates by a sole species of seed predator came from the highest density of $U$. solstitialis (in the absence of $R$. conicus). No combination of the two seed predators produced a lower population growth rate.

TABLE 2: Growth rate $(\lambda)^{1}$ predictions for nodding thistle populations exposed to various seed predator combinations, based on modifications to Shea \& Kelly (1998) matrix model.

\begin{tabular}{cccc}
\hline U. solstitialis & \multicolumn{3}{c}{ R. conicus initial density } \\
\cline { 2 - 4 } initial density & 0 & Low & High \\
\hline 0 & 2.2 & 2.2 & 1.7 \\
Low & 2.1 & 2.1 & 1.6 \\
High & 1.1 & 1.1 & 1.4 \\
\hline
\end{tabular}

${ }^{1} \lambda$ values lower than 1 indicate a population in decline; equal to 1 is a stable population; and greater than 1 is a growing population.

\section{DISCUSSION}

In the early stages of the debate on the choice between $R$. conicus and U. solstitalis, Zwölfer (1973) claimed the first choice of nodding thistle biocontrol agent to be introduced into an invaded range should be $R$. conicus, because it is a highly fecund insect that distributes its many eggs on many capitula. In addition, Zwölfer claimed it is the inferior competitor of the two, and thus would not jeopardise a future introduction of $U$. solstitialis in case seed reduction was not satisfactory. The galls formed by U. solstitialis, on the other hand, render a considerable amount of the receptacle unsuitable for other herbivores and would therefore jeopardize future introductions of $R$. conicus.

In contrast, Harris (1989) claimed that woody gall formers should be the first choice for biological control of Cardueae weeds, because (1) the strong metabolic sink they produce utilises resources from the whole plant, not just the receptacle, (2) they are highly gregarious and (3) their limited dispersal assists in establishing populations while reducing dispersal-related mortality. Furthermore, Harris's advice that no insect should be introduced that might reduce the impact of woody gall formers, relates to a concern that receptacle feeders, such as $R$. conicus, were likely to displace gall formers, such as U. solstitialis. Harris further pointed out that Zwölfer's criteria should also have led to selection of $U$. solstitialis as the first agent to introduce, because this is the inferior competitor - it is displaced by $R$. conicus when they attack simultaneously, but not when $R$. conicus's attack comes after the gall had hardened (Harris 1991). Apart from Zwölfer (1973), all evidence indicates that $R$. conicus is the superior competitor (Woodburn \& Briese 1996, Woodburn 1996b, McNeill \& Fletcher 2005), or at least not inferior (Moller-Joop \& Schroeder 1986). The present results support the superiority of $R$. conicus as a competitor, with $U$. solstitialis numbers per capitulum reduced by $46-93 \%$ in the presence of $R$. conicus (Table 1). Moreover, it appears from Table 1 that $R$. conicus benefited from the presence of $U$. solstitialis, as $R$. conicus numbers increased. 
Yet, from Table 2 it appears that nodding thistle biocontrol does not improve with this increase in $R$. conicus numbers.

The timing of attack has been identified by Harris (1989) as a major factor affecting the outcome of the inevitable competition between two species ovipositing at the same time on the same niche. In New Zealand, $R$. conicus starts ovipositing before U. solstitalis (McNeill \& Fletcher 2005), and the present study shows that they prefer the same plant and capitula characteristics for oviposition. This exposes $U$. solstitialis larvae to predation by $R$. conicus before the gall hardens (Harris 1989). Urophora solstitialis larvae provide better nutrition compared to the receptacle tissue, thus such predation may be the reason for the increase in $R$. conicus numbers in the presence of U. solstitialis that was apparent (Table 1).

Other factors may affect these two biocontrol agents' populations. In Australia, for example, $U$. solstitialis suffers from a new population regulation factor, where most adults emerge too early in the spring and die before any nodding thistle capitula are available for oviposition (Woodburn \& Cullen 1996). Sheppard \& Woodburn (1996) stressed that, while in their native range $R$. conicus and $U$. solstitialis may be regulated to some extent by their natural enemies, in their introduced range, where they are released from such pressure, they may suffer from more intraspecific competition. Indeed, Woodburn (1996b) found that in early nodding thistle capitula that are very heavily attacked by $R$. conicus, no seeds are produced, but also no weevils complete their life cycle, as these capitula tend to abort prematurely.

Shea \& Kelly (2004) predicted that of the three agents introduced to New Zealand (only two of these were considered in the present study), R. conicus would have the least effect on nodding thistle population growth. Not only does this weevil provide insufficient seed predation, but the present study has now also shown that it out-competes the first generation of $U$. solstitialis, which inevitably results in a smaller second generation of the latter. Sadly, food supply (thistle capitula) is certainly not the limiting factor for this second generation of $U$. solstitialis.

It is apparent from Table 2 that $U$. solstitialis alone, at high densities, would be predicted to reduce nodding thistle population growth rate substantially, while high densities of $R$. conicus cause a smaller reduction in thistle population growth rate due to interference with $U$. soltitialis. Yet, it is also obvious that no combination of $U$. solstitialis and $R$. conicus is predicted to cause populations in New Zealand to decline. Indeed, as suggested by Shea \& Kelly (2004), it is the combination of $U$. solstitialis and a third biocontrol agent, a root crown feeder, that will be most likely to cause this thistle to decline.

\section{ACKNOWLEDGEMENTS}

We thank Janette Beaton, Kat Bushman, Emry Dolev, Helen Parish, Nicolette Le Cren, Lindsay Smith and Caroline Thomson for field and lab assistance; Kathrin Affeld, the Carasuks, Jenny Ladley and Maggie Tisch for preparation of the cages; and Ottar Bjørnstad and Dave Saville for statistical advice. The study was funded by the Foundation for Research, Science and Technology.

\section{REFERENCES}

Harris P 1989. Feeding strategy, coexistance and impact of insects in spotted knapweed capitula. Proceedings of the VII International Symposium on Biological Control of Weeds. Pp. 39-47.

Harris P 1991. Classical Biocontrol of Weeds - Its Definition, Selection of Effective Agents, and Administrative Political Problems. Canadian Entomologist 123: 827-849.

Jessep CT 1989. Carddus nutans L., nodding thistle (Asteraceae). In: Cameron PJ, Hill RL, Bain J, Thomas WP ed. A Review of Biological Control of Invertebrate Pests and Weeds in New Zealand 1874 to 1987 . CAB International, Wallingford, U.K. Pp. 339-342. 
Kelly D, McCallum K 1990. Demography, seed biology and biological control of Carduus nutans in New Zealand. Palmer JP ed. The Biological Control of Invasive Plants: Proceedings of a Conference of the British Ecological Society. Pp. 72-79.

Kelly D, Wood R 1991. Why nodding thistle receptacle weevil destroys so little nodding thistle seed in Canterbury. Proceedings of New Zealand Weed and Pest Control Conference 44: 280-283.

McNeill MR, Fletcher CJ 2005. Interspecific competition between Rhinocyllus conicus and Urophora solstitialis L. on nodding thistle in Canterbury? New Zealand Plant Protection 58: 140-147.

Moller-Joop H, Schroeder D 1986. Urophora solstitialis L. (Diptera: Tephritidae) a candidate for biological control of plumeless thistle (Carduus acanthoides L.) in Canada. C.A.B Final screening report. 23 pp.

R Development Core Team 2006. R: A language and environment for statistical computing. R Foundation for Statistical Computing, Vienna, Austria.

Shea K, Kelly D 1998. Estimating biocontrol agent impact with matrix models: Carduus nutans in New Zealand. Ecological Applications 8: 824-832.

Shea K, Kelly D 2004. Modeling for management of invasive species: Musk thistle (Carduus nutans) in New Zealand. Weed Technology 18: 1338-1341.

Shea K, Kelly D, Sheppard AW, Woodburn TL 2005. Context-dependent biological control of an invasive thistle. Ecology 86: 3174-3181.

Sheppard AW, Woodburn T 1996. Population regulation in insects used to control thistles: can this predict effectiveness? In: Floyd RB, Sheppard AW, De Barro PJ ed. Frontiers of Population Ecology. CSIRO publishing, Melbourne. Pp. 277-290

Woodburn TL 1996a. Reduction of seed set in nodding thistle (Carduus nutans) by the seed-fly, Urophora solstitialis, in Australia. In: McPheron BA, Steck GJ ed. Fruit Fly Pests: A World Assessment of Their Biology and Management. St. Lucie Press, Delray Beach, Florida, USA. Pp. 165-169

Woodburn TL 1996b. Interspecific competition between Rhinocyllus conicus and Urophora solstitialis, two biocontrol agents released in Australia against Carduus nutans. Moran VC, Hoffmann JH ed. Proceedings of the IX International Symposium on Biological Control of Weeds. Pp. 409-415.

Woodburn TL, Briese DT 1996. The contribution of biological control to the management of thistles. Plant Protection Quarterly 11: 250-253.

Woodburn TL, Cullen JM 1996. Impact of Rhinocyllus conicus and Urophora solstitialis on seed set in Carduus nutans in Australia. Hind NJ ed. International Compositae Conference. Pp 307-319.

Woodburn TL, Sheppard AW 1995. Urophora solstitialis, a potential biological control agent for Carduus nutans in Australia. Delfosse ES, Scott RR ed. Proceedings of the VIII Symposium on Biological Control of Weeds. p. 415.

Zwölfer H 1973. Competition and coexistance in phytophagous insects attacking the heads of Carduus nutans L. Proceedings of the II International Symposium on Biological Control of Weeds. Pp. 74-77. 